\title{
PENGGUNAAN ROKOK ELEKTRIK DAN NIAT MEROKOK (TEMBAKAU) DI KALANGAN REMAJA : PINTU GERBANG PEROKOK MUDA?
}

\author{
Salma Balqis Syafira \\ IIK Surya Mitra Husada (Ilmu Kesehatan Masyarakat) \\ Syafirasalmabalqis@gmail.com
}

\begin{abstract}
ABSTRAK
Pendahuluan : Saat ini fenomena rokok elektrik tidak hanya pada kalangan dewasa, melainkan juga banyak terjadi di kalangan remaja. Perlu diketahui, semakin banyaknya penggunaan rokok elektrik pada remaja akan memunculkan sebuah masalah baru yaitu penggunaan rokok elektrik pada remaja akan mempengaruhi niat remaja untuk menggunakan rokok tembakau di masa yang akan datang. Artikel ini bertujuan untuk mengeksplorasi hubungan antara penggunaan rokok elektrik pada remaja dengan niat menggunakan rokok tembakau pada kalangan remaja di masa yang akan datang.

Hasil : Penelitian saat ini menunjukkan bahwa adanya peningkatan penggunaan rokok elektrik pada remaja hingga saat ini. Faktor yang mempengaruhi semakin banyaknya penggunaan rokok elektrik pada remaja adalah persepsi remaja terkait rokok elektrik, pengaruh orang tua dan teman sebaya serta mudahnya keterjangkauan dan ketersedian rokok elektrik. Penelitian juga menunjukkan hasil bahwa terdapat hubungan antara penggunaan rokok elektrik dan niat menggunakan rokok tembakau di kalangan remaja. Hal ini berarti remaja yang menggunakan rokok elektrik cenderung akan menggunakan rokok tembakau kedepannya dibandingkan dengan remaja yang tidak menggunakan rokok elektrik.

Kesimpulan : Perlunya sosialisasi terhadap masyarakat khususnya remaja terkait dampak rokok elektrik dan perlunya regulasi pemerintah terkait distribusi rokok elektrik.
\end{abstract}

\section{LATAR BELAKANG}

Masalah tembakau merupakan salah satu ancaman terbesar kesehatan masyarakat yang dihadapi dunia saat ini. Fenomena rokok sudah menjadi masalah kesehatan dengan tingkat kematian yang cukup tinggi, hampir terjadi lima juta kematian karena penggunaan rokok langsung dan lebih dari enam ratus ribu kematian non perokok akibat dari paparan tidak langsung dari perokok. Sekitar 1 orang meninggal dari 10 orang dewasa setiap enam detik karena rokok. Telah diperkirakan hampir setengah dari kurang lebih 1,3 miliar perokok di seluruh di dunia saat ini akhirnya akan mati akibat dari penyakit yang berhubungan dengan rokok (WHO, 2013) 
Menurut laporan WHO (2009), diperkirakan lebih dari 5 juta kematian setiap tahun di seluruh dunia yang diakibatkan karena rokok dan umunya terjadi di negara-negara dengan pendapatan perkapita rendah dan sedang. Diperkirakan tahun 2030 rokok akan membunuh lebih dari 8 juta orang di selruh dunia tiap tahunnya dan $80 \%$ terjadi di negara-negara dengan pendapatan perkapita yang rendah dan sedang. Laporan WHO juga menjelaskan selain berbahaya bagi perokoknya, melainkan juga berbahaya bagi orang-orang disekitarnya yang menghirupnya atau sebagai perokok pasif atau second hand smoker. Selain itu, juga tidak ada batas ambang aman bagi perokok pasif dimana diperkirakan sudah sepertiga penduduk di dunia sudah menjadi perokok pasif. Rokok elektrik pertama kali diciptakan oleh salah satu perusahaan di cina pada tahun 2003 dan menyebar dengan sangat cepat ke seluruh belahan dunia. Secara umum sebuah rokok elektrik terdiri dari 3 bagian yaitu baterai, atomizar (bagian yang memanaskan dan menguapkan larutan nikotin), dan catridge (larutan nikotin) (Electronic Cigarette Association, 2009). Rokok elektrik pernah digunakan sebagai alat bantu program berhenti merokok, namun paraktik tersebut saat ini sudah tidak dianjurkan oleh Electronic Cigarette Association (ECA) dan Food Drug Association (FDA). Meskipun demikian, berdasarkan hasil survei besar yang telah dilakukan, mayoritas (81\% responden) memilih alasan menggunakan rokok elektrik sebagai alternatif untuk berhenti merokok (Farsalinos et al, 2014).

Pada awalnya, rokok elektrik dianggap sebagai produk yang aman bagi kesehatan karena larutan nikotin yang terdapat di rokok elektrik hanya terdiri sari campuran air, propilen glikol, zat penambah rasa, aroma tembakau, dan senyawa senyawa lainnya yang tidak mengandung TAR, tembakau, dan zat toksik lainnya yang ada pada rokok tembakau (William et al, 2010). Semakin maraknya masyarakat yang menggunakan rokok elektrik, FDA di Amerika melakukan penelitian terkait rokok elektrik dan hasil menemukan bahwa rokok eketronik mengandung Tobacco Spesific Nitrosamin (TSNA) yang bersifat toksik dan Diethy Glycol (DEG) yang dikenal sebagai karsinogen. Hal tersebut membuat FDA mengeluarkan peringatan tentang bahaya toksik dan karsinogen di dalam rokok elektrik sehingga adanya pembatasan distribusi dan penuualan rokok elektrik di Amerika dan beberapa negara lain (US FDA, 2011). American Lung 
Association (2015) menyebutkan bahwa rokok elektrik bukan merupakan metode yang efektik untuk upaya berhenti merokok.

Penelitian ASH Britain (2014) menunjukkan alasan menggunakan rokok elektrik karena ingin berhenti merokok sebanyak 38\% responden dan karena ingin mengurangi jumlah rokok tembakau yang dikonsumsi sebanyak 25\% responden. Selain itu, sebanyak 35\% responden setuju jika rokok elektrik tidak akan berdampak buruk bagi kesehatan masyarakat. Tentunya hal ini menunjukkan bahwa masih kurang jelasnya informasi terkait bahaya dan keamanan dari penggunaan rokok elektrik itu sendiri sehingga menyebabkan semakin banyaknya penggunaan rokok elektrik di kalangan masyarakat. Penelitian Ambrose et al (2014) menjelaskan bahwa belum gencarnya sosialisasi terkait bahaya penggunaan rokok elektrik maupun pencantuman label peringatan menyebabkan masih simpang siurnya informasi terkait keamanan penggunaan rokok elektrik.

Saat ini rokok elektrik tidak hanya disukai kaum dewasa saja, tetapi juga disukai sebagian besar kaum remaja. Selain itu, jumlah pengguna rokok elektrik di dunia juga semakin meningkat terutama di kalangan remaja. Survei yang dilakukan di Kanada terhadap 2.892 Sekolah menengah menunjukkan bahwa 28\% siswa telah mencoba untuk menggunakan rokok elektrik dengan larutan nikotin (OTRU, 2015). Di Amerika Serikat, terjadi peningkatan proporsi pelajar yang pernah menggunakan rokok elektrik pada remaja dalam kurun waktu 2014-2015 dimana dari 27,3\% pada tahun 2014 menjadi 37,7\% pada tahun 2015 (US Department of Health and Human Services, 2016). Paparan nikotin pada remaja dapat memberikan dampak pada ingatan dan pengaturan emosional pada remaja (England et al, 2015).

Selain itu, penggunaan rokok elektrik di remaja dihubungkan dengan upaya untuk berhenti merokok. Hal ini sejalan dengan penelitian Tavalocci et al (2016) yang menunjukkan adanya hubungan antara remaja yang merokok (tembakau) dengan penggunaan rokok elektrik. Hal ini berhubungan dengan riwayat remaja menggunakan rokok tembakau yang berubah menggunakan rokok elektrik karena ingin berhenti merokok (tembakau). Faktor pengaruh teman sebaya juga dapat mempengaruhi penggunaan rokok elektrik pada remaja. Selain bentuk adopsi informasi, remaja yang cenderung memiliki teman sebaya 
pengguna rokok elektrik akan lebih udah mengadopsi perilaku teman sebayanya sehingga lebih mungkin untuk menggunakan rokok elektrik.

Penelitian Barrington et al (2015) melaporkan bahwa remaja yang menggunakan rokok elektrik $>6$ kali lebih tinggi mempunyai niat untuk menggunakan rokok tembakau dibandingkan dengan yang tidak menggunakan rokok elektrik dan sebanyak $40 \%$ remaja yang menggunakan rokok elektrik mempunyai niat untuk menggunakan rokok tembakau rata-rata selama 16 bulan kedepan. Sejalan dengan penelitian Primack et al (2015) yang menunjukkan hasil bahwa 11 dari 16 remaja yang menggunakan rokok elektrik memiliki perkembangan untuk menggunakan rokok tembakau setelah di tindak lanjuti selama 1 tahun. Pada prinsipnya, ketersediaan rokok elektrik pada remaja mungkin dapat menunda niat mereka yang ingin menggunakan rokok tembakau atau bahkan dapat menjadi pintu masuk kalangan remaja untuk memulai menggunakan rokok tembakau.

\section{KESIMPULAN}

Penggunaan rokok elektrik atau yang sering disebut dengan vape pada remaja saat ini mengalami peningkatan terus menerus. Beberapa peneliti menemukan terdapat hubungan yang kuat antara penggunaan rokok elektrik dengan penggunaan rokok tembakau di kalangan remaja. Remaja yang menggunakan rokok elektrik memiliki kecenderungan untuk menggunakan rokok tembakau di masa yang akan datang dibandingkan dengan remaja yang tidak menggunakan rokok elektrik. Dengan adanya masalah ini, diperlukan sosialiasi kepada masyarakat khususnya untuk remaja terkait kandungan bahan dan bahaya akan penggunaan rokok elektrik dan rokok tembakau serta diperlukan regulasi dari pemerintah untuk mengatur distribusi penjualan rokok elektrik sehingga masyarakat khususnya remaja tidak mudah untuk menjangkau dan mendapatkan rokok elektrik tersebut. 


\section{DAFTAR PUSTAKA}

Ambrose, B.K.; Rostron, B.L.; Johnson, S.E.; Portnoy, D.B.; Apelberg, B.J.; Kaufman, A.R. \& Choiniere, C.J. Perceptions of The Relative Harm of Cigarettes and E-cigarettes among U.S. Youth. Am. J. Prev. Med. 2014, 5360.

American Lung Association.. American Lung Association Statement on ECigarette. 2015. Retrivied from: http://www. lung.org/stopsmoking/tobacco-controladvocacy/federal/e-cigarettes.html. (Diakses 25 Desember 2019)

Action on Smoking \& Health (ASH) Britain. Use of Electronic Cigarette in Great Britain. 2014. ASH: London

Barrington-Trimis, JL.; Berhane, K; Unger, JB. Psychosocial factors associated with adolescent electronic cigarette and cigarette use. Pediatrics. 2015, 136(2), 308-317.

England, L.J.; Bunnell,R.E.; Pechacek, T.F.; Tong V.T.; McAfee, T.A. Nicotine and the developing human: a neglected element in the electronic cigarette debate. Am J Prev Med. 2015, 49(2), 286-293.

Goniewicz, M.L.; Knysak, J.; Gawron, M.; et al. Levels of selected carcinogens and toxicants in vapour from electronic cigarettes. Tob Control. 2014, 23(2), 133-139.

Primack, B.A.; Samir, S.; Michael, S.; Michael, J.F.; James, D.S. Progression to Traditional Cigarette Smoking After Electronic Cigarette Use among US Adolescents and Young Adults. JAMA Pediatrics. 2015, 169 (11), 10181023.

The Ontario Tobacco Research Unit (OTRU). Introduction to RECIG: Research on E-cigarette. 2015, Toronto, The Ontario Tobacco Research Unit.

Tavolacci, M.P.; Anca, V.; Lucia, R.; Gayatri, K.; Laurence, K.; Joel, L. Patterns of Electronic Cigarette Use in Current and Ever Users among Colledge Students in France : A Cross Sectional Study. BMJ Open. 2016, 6, 1-10

U.S. Department of Health and Human Services. E-Cigarette Use Among Youth and Young Adults: A Report of the Surgeon General Executive Summary. 2016. Atlanta.

World Health Organization, Study Group on Tobacco Regulation. Report on the Scientific Basis of Tobacco Product Regulation: Third Report of a WHO Study Group. 2009, Geneva, World Health Organization. 